\title{
Retracted: Process Evaluation of a Positive Youth Development Program in Hong Kong Based on Different Cohorts
}

\author{
The Scientific World Journal \\ Received 26 March 2014; Accepted 26 March 2014; Published 8 April 2014
}

Copyright (C 2014 The Scientific World Journal. This is an open access article distributed under the Creative Commons Attribution License, which permits unrestricted use, distribution, and reproduction in any medium, provided the original work is properly cited.

The paper titled "Process Evaluation of a Positive Youth Development Program in Hong Kong Based on Different Cohorts" [1], published in The Scientific World Journal, has been retracted as it is found to contain a substantial amount of material, without referencing, from the published article titled "Process Evaluation of a Positive Youth Development Program: Project P.A.T.H.S," Ben M. F. Law and Daniel T. L. Shek, Research on Social Work Practice, vol. 21, no. 5, pp. 539548, 2011.

\section{References}

[1] B. M. F. Law and D. T. L. Shek, "Process evaluation of a positive youth development program in Hong Kong based on different cohorts," The Scientific World Journal, vol. 2012, Article ID 736730, 9 pages, 2012. 